\title{
Purification and properties of extracellular mutacin, a bacteriocin from Streptococcus sobrinus
}

\author{
JuAN P. Loyola-Rodriguez, ${ }^{1}$ ICHIJIRo Morisaki, ${ }^{2} \mathrm{~K}$ YOICHI KITAMURA ${ }^{3}$ and \\ SHIGEYUKI HAMADA ${ }^{1 *}$ \\ ${ }^{1,2,3}$ Departments of Oral Microbiology ${ }^{1}$, Dentistry for the Handicapped ${ }^{2}$, and Pedodontics ${ }^{3}$, \\ Osaka University Faculty of Dentistry, Yamadaoka, Suita-Osaka 565, Japan
}

(Received 24 July 1991; revised 8 October 1991; accepted 15 October 1991)

\begin{abstract}
Mutacin MT6223, a cell-free bacteriocin produced by Streptococcus sobrinus MT6223, was purified by ammonium sulphate precipitation, chromatofocusing with PBE 94 and column chromatography on SP Sephadex C-25. The specific activity of the purified mutacin was increased 1950 -fold with a recovery of $9.7 \%$. The molecular mass of the purified mutacin preparation was estimated to be $6.5 \mathrm{kDa}$. The mutacin activity was stable from pH 27 , and was resistant to treatment at $100^{\circ} \mathrm{C}$ for $20 \mathrm{~min}$. It was inactivated by papain or ficin digestion, and was partially inhibited by $\alpha$-chymotrypsin. The mutacin was found to be active against strains of serotypes $c, e$ and $f$ of Streptococcus mutans and the addition of purified mutacin MT6223 to growing cells of $S$. mutans MT8148 resulted in a rapid inhibition of incorporation of $\left[{ }^{3} \mathrm{H}\right]$ thymidine, $\left[{ }^{3} \mathrm{H}\right]$ uracil or $\mathrm{L}-\left[{ }^{3} \mathrm{H}\right]$ glutamic acid into DNA, RNA or protein, respectively. Specific pathogen-free Fischer rats fed diet 2000 and infected with $S$. mutans MT8148R showed significantly fewer caries and lower plaque scores when mutacin was administered through drinking water. The present study demonstrates that mutacin MT6223 inhibited the growth of mutans streptococci. Thus, mutacin MT6223 may be a candidate for use in dental caries prevention.
\end{abstract}

\section{Introduction}

Bacteriocins are antimicrobial polypeptides produced by some strains of various bacterial species. Typical bacteriocins, particularly those derived from Gramnegative bacterial species, have a narrow inhibitory spectrum of activity against homologous or related species. Clinically isolated strains of mutans streptococci have been reported to produce bacteriocin-like substances that exhibit a wide spectrum of antibacterial activity, and the term mutacin has been proposed to describe these antibacterial substances (Hamada \& Ooshima, 1975a). The mutacin activity of mutans streptococci has been well-recognized on agar plates, but only a few strains of Streptococcus mutans have been reported to produce cell-free mutacin in liquid culture (Hamada \& Ooshima, 1975b; Delisle, 1986). Bacteriocin production is affected by cultural conditions such as composition of the culture medium, incubation time, and $\mathrm{pH}$. Paul \& Slade (1975) found a bacteriocin from $S$. mutans GS5 (serotype $c$ ) with a molecular mass of more than $20 \mathrm{kDa}$ which was non-diffusible. Hillman et al.

* Author for correspondence. Tel. 68784755 .
(1984) reported that a serotype $c$ strain of $S$. mutans produced a mutacin with a molecular mass $<1 \mathrm{kDa}$, and Ikeda et al. (1982) described a mutacin from $S$. mutans C3603, a serotype $c$ strain, with a molecular mass estimated to be $4.8 \mathrm{kDa}$.

It has been suggested that strains of $S$. mutans belonging to serotypes $c$ or $e$ are more potent producers of bacteriocin-like inhibitory factors against other mutans streptococci (Hamada \& Ooshima, 1975a). The bacteriocinogeny of $S$. mutans may modulate local bacterial ecology in dental plaque on tooth surfaces. In fact, using the experimental caries system in rats or hamsters, it was shown that isolated mutacin C3603 and a bacteriocin from Staphylococcus epidermidis 1580 (i.e. staphylococcin 1580) exerted cariostatic activities (Ikeda et al., 1982; Fitzgerald et al., 1986). More recently, we reported that a mutacin-producing strain, Streptococcus sobrinus MT6223, clearly inhibited colonization on tooth surfaces by $S$. mutans MT6222, a mutacin-sensitive serotype $f$ strain (Kitamura et al., 1989). This study deals with the purification and characterization of extracellular bacteriocin from S. sobrinus MT6223 (mutacin MT6223) and its caries inhibitory activity in vivo. 


\section{Methods}

Bacterial strains and growth conditions. S. sobrinus MT6223, a serotype $g$ strain of mutans streptococci, was used as a producer of mutacin (Kitamura et al., 1989). MT6223 was grown in a diffusate medium of TTY broth (Hamada \& Torii, 1978) at $37^{\circ} \mathrm{C}$ for $24 \mathrm{~h}$. Culture supernatant was obtained by centrifugation $\left(10000 \mathrm{~g}, 20 \mathrm{~min}, 4^{\circ} \mathrm{C}\right)$. Indicator bacterial strains used for determining sensitivity to the mutacin MT6223 included $S$. mutans MT8148, MT8148R (the suffix R refers to a streptomycin-resistant mutant), MT4263, NG71, Ingbritt and GS5 (serotype c); MT703R, MT3567R and LK3 (serotype e); MT6222, OMZ 175 and MT3940 (serotype $f$ ); and $S$. sobrinus OMZ 176, B13R and MT4502 (serotype $d$ ); 6715, MT6223, and MT4532 (serotype g). Streptococcus cricetus E49 and HS6 (serotype a); Streptococcus rattus FA1 and BHT (serotype b); and Streptococcus downei $\mathrm{MFe} 28$ (serotype $h$ ) were also included in this study. These organisms were grown on Trypticase soy agar (TSA; BBL Microbiology Systems) and were subcultured once a week. Other bacterial strains were selected from the culture collection at the Department of Oral Microbiology, Osaka University Faculty of Dentistry, Osaka, Japan.

Bacteriocin assay. The activity of mutacin MT6223 was estimated by using twofold dilutions of the test preparations and aseptically dispensing $100 \mu \mathrm{l}$ of each dilution into wells of sterile flat-bottomed 96-well microtitre plates (Corning). Indicator organisms $\left(6 \times 10^{4}\right.$ cells $\mathrm{ml}^{-1}$ ) of $S$. mutans MT8148R were then inoculated into the wells in $100 \mu \mathrm{l}$ Brain Heart Infusion broth (BHI, Difco) with $1 \%(w / v)$ sucrose and $250 \mu \mathrm{g}$ streptomycin $\mathrm{ml}^{-1}$. The plates were incubated at $37^{\circ} \mathrm{C}$ for $18 \mathrm{~h}$, and the supernatant was removed from the wells. The plates were then fixed with $0.1 \%(\mathrm{v} / \mathrm{v})$ glutaraldehyde for $5 \mathrm{~min}$ at room temperature, and stained with $0.5 \%(\mathrm{w} / \mathrm{v})$ crystal violet for $5 \mathrm{~min}$. The wells were then washed with water and dried. An arbitrary unit (AU) of mutacin was defined as the reciprocal of the highest dilution showing visible inhibition of the growth of the indicator organisms (Dajani et $a l .$, 1976). Specific activities were expressed in terms of AU (mg protein $)^{-1}$, after quantification of protein in the samples by Lowry's method.

The bactericidal activity of mutacin MT6223 was determined by measuring the decrease over time in the number of c.f.u. of the sensitive indicator strains grown in BHI broth. Various concentrations (2.5$100 \mathrm{AU} \mathrm{ml}^{-1}$ ) of purified mutacin MT6223 were added to $5 \mathrm{ml} \mathrm{BHI}$ broth. Then $1 \times 10^{4}$ c.f.u. of the indicator strains were added, and the suspension was incubated at $37^{\circ} \mathrm{C}$. The viable counts in the reaction mixture were determined by colony counting using Mitis Salivarius (MS; Difco) agar plates at 6,12, 18 and $24 \mathrm{~h}$ incubation periods. The growth inhibition was determined as the difference in viable counts at $24 \mathrm{~h}$ between the samples with or without mutacin plated on MS agar and incubated at $37^{\circ} \mathrm{C}$ for $48 \mathrm{~h}$. Production of mutacin in the agar medium was examined by the stab culture technique (Hamada \& Ooshima, 1975b).

Purification of mutacin. Mutacin was purified from the culture supernatant of $S$. sobrinus MT6223 grown in TTY (81) broth. Solid ammonium sulphate $\left(351 \mathrm{~g} \mathrm{l}^{-1}\right)$ was added to the supernatant to $55 \%$ saturation. The precipitate was collected by centrifugation, dissolved in $25 \mathrm{~mm}$-imidazole/ $\mathrm{HCl}$ buffer ( $\mathrm{pH} \mathrm{6.2}$ ), and applied to a column of Polybuffer PBE 94 . Fractions $(15 \mathrm{ml})$ showing mutacin activity were demonstrated in the void volume portions. Active mutacin fractions were pooled, concentrated by precipitation with $55 \%$ saturated ammonium sulphate and dialysed overnight against $10 \mathrm{~mm}$-sodium phosphate buffer ( $\mathrm{pH} \mathrm{5.0)}$. The concentrated mutacin from the chromatofocusing column was applied to an SP Sephadex C-25 (Pharmacia) column $(1.6 \times 10 \mathrm{~cm})$ equilibrated with $50 \mathrm{~mm}$-sodium phosphate buffer (pH 5.0). The column was eluted with a linear gradient of $50 \mathrm{~mm}$-sodium phosphate buffer (pH $5.0 ; 150 \mathrm{ml}$ ) to $50 \mathrm{~mm}$ sodium phosphate buffer $(\mathrm{pH} 7.0 ; 150 \mathrm{ml})$ and $15 \mathrm{ml}$ fractions were collected. All buffers used for purification were sterilized by filtration through a membrane filter $(0.45 \mu \mathrm{m}$ pore size $)$.

Physico-chemical properties. To determine the heat stability of the purified mutacin, mutacin MT6223 was kept at 37,60 and $80^{\circ} \mathrm{C}$ for $1 \mathrm{~h}$, $100{ }^{\circ} \mathrm{C}$ for $20 \mathrm{~min}$, and at $120^{\circ} \mathrm{C}$ for 5 or $20 \mathrm{~min}$. The pH stability was estimated by incubating mutacin for $2 \mathrm{~h}$ at $37^{\circ} \mathrm{C}$ in filter-sterilized $50 \mathrm{~mm}$ buffers covering the following ranges: glycine $/ \mathrm{HCl}$ buffer (pH 2-3), sodium acetate buffer ( $\mathrm{pH} \mathrm{4-5),} \mathrm{sodium} \mathrm{phosphate} \mathrm{buffer}$ (pH 6-8) and sodium carbonate buffer (pH 9-11). The effect of various enzyme treatments on mutacin MT6223 activity was determined by incubating mutacin $(640 \mathrm{AU})$ with the enzyme to be tested at $37^{\circ} \mathrm{C}$ for $1 \mathrm{~h}$. The following filter-sterilized enzymes were examined: papain type III and ficin (dissolved in $1 \mathrm{mM}$-EDTA, $67 \mathrm{~mm}$-2-mercaptoethanol, and $5.5 \mathrm{~mm}$-cysteine/ $\mathrm{HCl}$ buffer, $\mathrm{pH} 2.8$ ), and trypsin and lipase (in Tris/ $\mathrm{HCl}$ buffer, $\mathrm{pH} \mathrm{7.0}$ and 6.0). Phospholipase $\mathrm{A}$, catalase, $\alpha$-chymotrypsin, pronase $P$, protease XIV, protease XVII (B) and protease XXVI were dissolved in $10 \mathrm{~mm}$-potassium phosphate buffer (pH 7.0). All reagents were purchased from Sigma. After treatment with the enzyme, the remaining mutacin activity was estimated in 96-well plates as described above.

SDS-PAGE. Slab gels were prepared as described by Laemmli \& Favre (1973). Mutacin MT6223 $(20 \mu \mathrm{g})$ was heated at $100^{\circ} \mathrm{C}$ for $5 \mathrm{~min}$ in $10 \mathrm{mM}$-Tris $/ \mathrm{HCl}$ buffer (pH 6.8), containing $1 \%(\mathrm{w} / \mathrm{v}) \mathrm{SDS}, 1 \%(\mathrm{v} / \mathrm{v})$ 2-mercaptoethanol, $20 \%(\mathrm{v} / \mathrm{v})$ glycerol, and $10 \%(\mathrm{w} / \mathrm{v})$ sucrose. Electrophoresis was done at $4{ }^{\circ} \mathrm{C}$ for $3 \mathrm{~h}$ using a $15 \%$ (w/v) running gel and a $4 \%(w / v)$ stacking gel $(8.5 \times 7.7 \times 0.1 \mathrm{~cm})$ with and without $0.1 \%$ SDS. Ovalbumin $(43 \mathrm{kDa})$, carbonic anhydrase $(29 \mathrm{kDa})$, $\beta$-lactoglobulin $(18.4 \mathrm{kDa})$, lysozyme $(14.3 \mathrm{kDa})$, bovine trypsin $(6.2 \mathrm{kDa})$, insulin $\mathrm{B}$ and $\mathrm{C}(3.4 \mathrm{kDa})$, and insulin $\mathrm{A}(2.3 \mathrm{kDa})$ were used as calibration markers for determination of molecular mass (BRL). The mutacin activity was located on the gel after electrophoresis by soaking the unstained gel for $18 \mathrm{~h}$ in a saline streptomycin solution $(250 \mu \mathrm{g}$ $\left.\mathrm{ml}^{-1}\right)$ to remove SDS, and then by embedding the gel in Trypticase soy soft agar $(0.8 \%, \mathrm{w} / \mathrm{v}$, agar) containing $S$. mutans MT8148R as the indicator strain (Hamada \& Ooshima, 1975b). Streptomycin $(250 \mu \mathrm{g}$ $\mathrm{ml}^{-1}$ ) was included in the wash buffer to prevent growth of contaminating bacteria. Identification of the position showing the inhibition zone of the bacterial growth was then compared with the protein band which developed in the gel stained with Coomassie blue run at the same time.

Incorporation of radioactive substrates. DNA, RNA and protein syntheses were measured by the incorporation of radioactive precursors $\left[{ }^{3} \mathrm{H}\right]$ thymidine, $\left[{ }^{3} \mathrm{H}\right]$ uracil or $\mathrm{L}-\left[{ }^{3} \mathrm{H}\right] \mathrm{glutamic}$ acid into the TCAprecipitable fraction in $S$. mutans MT8148 grown in synthetic FMC broth (Terleckyj et al., 1975) at $37^{\circ} \mathrm{C}$. Addition of $10 \mu \mathrm{Ci}(0.37 \mathrm{MBq})$ $\left[{ }^{3} \mathrm{H}\right]$ thymidine, $5 \mu \mathrm{Ci}(0 \cdot 185 \mathrm{MBq})\left[{ }^{3} \mathrm{H}\right]$ uracil, or $5 \mu \mathrm{Ci}(0 \cdot 185 \mathrm{MBq})$ $\mathrm{L}-\left[{ }^{3} \mathrm{H}\right]$ glutamic acid $\mathrm{ml}^{-1}$ was made to cultures with an $\mathrm{OD}_{640}$ of 0.4 . After 30 min incubation at $37^{\circ} \mathrm{C}$, the culture was divided into three fractions which were incubated with mutacin MT6223 (10 or $25 \mathrm{AU}$ $\left.\mathrm{ml}^{-1}\right)$ or buffer without mutacin to serve as the control. Samples $(1 \mathrm{ml})$ of the cultures were taken at intervals and mixed with $0.5 \mathrm{ml}$ cell suspension containing $1.5 \mathrm{mg}$ (dry mass) cells of unlabelled $S$. mutans MT8148. Then, $1 \mathrm{ml} \mathrm{10 \% (v/v)} \mathrm{TCA} \mathrm{solution} \mathrm{was} \mathrm{added} \mathrm{to} \mathrm{the} \mathrm{above}$ cell suspension, and the precipitate was collected by centrifugation $\left(5000 \mathrm{~g}, 20 \mathrm{~min}, 4^{\circ} \mathrm{C}\right)$. All the samples were washed extensively in saline to remove free radioactive substrate and the radioactivity of the precipitate was quantified by an LRB 1214 RackBeta liquid scintillation counter. All experiments were repeated at least three times and assays were run in triplicate. 
Experimental dental caries induction in rats. Specific pathogen-free Fischer rats (Charles River Japan), 15-d old, were used. Four groups of rats (12 rats per group) were given powdered diet CE-2 containing tetracycline [ $4 \mathrm{mg}\left(\mathrm{g} \mathrm{diet}^{-1}\right]$, and deionized water containing penicillin $\mathrm{G}\left(4000 \mathrm{U} \mathrm{ml}^{-1}\right)$ ad libitum for $2 \mathrm{~d}$. Group A non-infected rats were fed caries-inducing diet 2000 containing $56 \%$ sucrose. Group B, C and D rats were infected orally on two successive days with $S$. mutans MT8148R $\left(0.1 \mathrm{ml} 1 \times 10^{9}\right.$ c.f.u. $\mathrm{ml}^{-1}$, twice a day $)$ and given diet 2000 . Then, group C and D rats were administered mutacin MT6223 (50 and $100 \mathrm{AU} \mathrm{ml}^{-1}$, respectively) in drinking water. The animals remained on this regimen for $55 \mathrm{~d}$. At the end of the experiment the rats were killed under ether anaesthesia in a $\mathrm{CO}_{2}$ atmosphere to prepare mandibular and maxillary specimens for the following examinations. Dental plaque accumulation on the molar teeth was evaluated by the procedure of Regolati \& Hotz (1972). The attached bacteria on the mandible were dispersed in saline using a sonicator, then ten-fold dilutions of the bacterial suspension were prepared with sterile saline, spread on MS agar plates containing streptomycin $\left(500 \mu \mathrm{g} \mathrm{ml}^{-1}\right)$ for counting total c.f.u. of $S$. mutans MT8148R, as described previously by Ooshima et al. (1991). Dental caries were scored by the method of Keyes (1944) as modified by Ooshima et al. (1981). Caries scores were analysed by Student's $t$ test.

\section{Results}

\section{Purification of mutacin MT6223}

The concentrate of culture supernatant of $S$. sobrinus MT6223 obtained by ammonium sulphate precipitation was applied on a Polybuffer PBE 94 column equilibrated with $25 \mathrm{~mm}$-imidazole/ $\mathrm{HCl}$ buffer ( $\mathrm{pH} \mathrm{6.2)}$. The mutacin was eluted without adsorbing to the column. The fractions containing mutacin activity were pooled and concentrated by ammonium sulphate precipitation. The concentrated mutacin was further purified by SP Sephadex C-25 column chromatography. A summary of a typical experiment is presented in Table 1 . The specific activity of mutacin was increased to $1950 \mathrm{AU}$ (mg protein $)^{-1}$ and the final purification was over 2000-fold with a recovery of $9.7 \%$. Furthermore, SDS-PAGE analysis revealed that mutacin MT6223 was purified to a single band with an apparent molecular mass of $6.5 \mathrm{kDa}$. The growth inhibition of the purified mutacin MT6223 was located on an unstained gel run at the same time

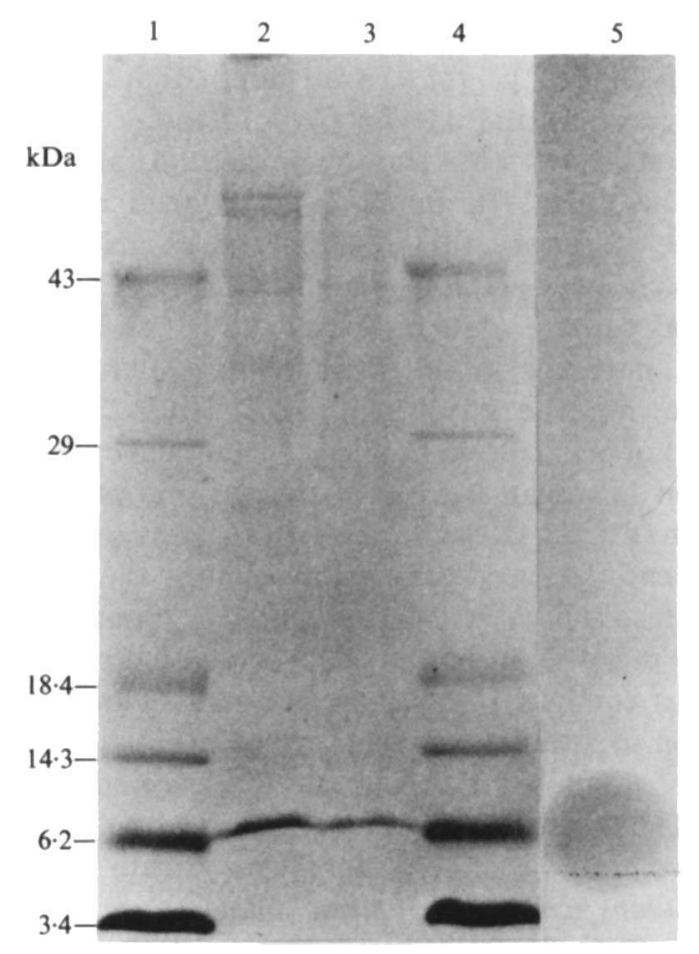

Fig. 1. SDS-PAGE of various preparations of mutacin MT6223. Lanes: 1 and 4, molecular mass markers; 2 , mutacin after chromatofocusing; 3, mutacin after SP Sephadex C-25 column; 5, mutacin activity, i.e. growth inhibition of the indicator strain on unstained gel.

after embedding the gel in soft agar inoculated with indicator organisms, i.e. S. mutans MT8148R (Fig. 1).

\section{Characteristics of purified mutacin MT6223}

Storage of purified mutacin preparations at various temperatures indicated that the activity was stable at $4{ }^{\circ} \mathrm{C}$ or in a frozen state $\left(-20\right.$ to $\left.-70^{\circ} \mathrm{C}\right)$ for at least 3 months. At room temperature, however, preparations of mutacin MT6223 lost some activity, decreasing in titre from 50 to $25 \mathrm{AU} \mathrm{ml}^{-1}$ after 4 weeks. The purified mutacin was stable to heating at $\mathrm{pH} 5 \cdot 0$, with no apparent decrease in the activity after $20 \mathrm{~min}$ at $100^{\circ} \mathrm{C}$.

Table 1. Purification of mutacin from culture supernatant of S. sobrinus MT6223

\begin{tabular}{lccccr}
\hline \hline \multicolumn{1}{c}{ Step } & $\begin{array}{c}\text { Total } \\
\text { protein } \\
(\mathrm{mg})\end{array}$ & $\begin{array}{c}\text { Total } \\
\text { activity } \\
(\mathrm{AU})\end{array}$ & $\begin{array}{c}\text { Specific } \\
\text { activity } \\
(\text { AU mg }\end{array}$ & $\begin{array}{c}\text { Recovery } \\
(\%)\end{array}$ & $\begin{array}{c}\text { Degree of } \\
\text { purification }\end{array}$ \\
\hline Culture supernatant & 84000 & 80000 & 0.95 & 100 & 1 \\
Ammonium sulphate & 1680 & 52800 & 31.4 & 66 & 33 \\
Chromatofocusing & 52 & 38400 & 738 & 48 & 775 \\
SP-Sephadex C-25 & 4 & 7800 & 1950 & 9.7 & 2048 \\
\hline \hline
\end{tabular}


However, mutacin activity was partially inactivated by heating at $120^{\circ} \mathrm{C}$ for $5 \mathrm{~min}$, and was completely destroyed by heating at $120^{\circ} \mathrm{C}$ for $20 \mathrm{~min}$.

The mutacin was stable in neutral and acidic conditions ( $\mathrm{pH} \mathrm{2-7),} \mathrm{but} \mathrm{was} \mathrm{inactivated} \mathrm{rapidly} \mathrm{in}$ alkaline conditions ( $\mathrm{pH} 8-11$ ). Purified mutacin was completely inactivated after digestion at $37^{\circ} \mathrm{C}$ for $1 \mathrm{~h}$ by ficin and papain, while protease XVI (B) and $\alpha$-chymotrypsin partially inhibited mutacin activity (results not shown). The effect of mutacin MT6223 on the viability of $S$. mutans MT8148 was examined by counting c.f.u. on MS agar after incubation in the presence of mutacin (Fig. 2). Concentrations of mutacin over $10 \mathrm{AU}$ $\mathrm{ml}^{-1}$ clearly reduced the viable count of the indicator organisms, while smaller amounts of mutacin (5 or $2.5 \mathrm{AU} \mathrm{ml}^{-1}$ ) retarded the cell growth of the indicator strain as compared to the control without mutacin. A selection of strains of mutans streptococci were examined for their susceptibility to the purified mutacin MT6223 by the broth assay and by the stab culture assay in agar plates (Table 2). A significant growth inhibition of $S$. mutans strains (serotypes $c, e$ and $f$ ) was found by both methods. However, most strains of $S$. cricetus, $S$. rattus and $S$. sobrinus were insensitive to the purified mutacin by the broth assay. The mutacin also exhibited growth inhibition of strains of $S$. salivarius, $S$. milleri and

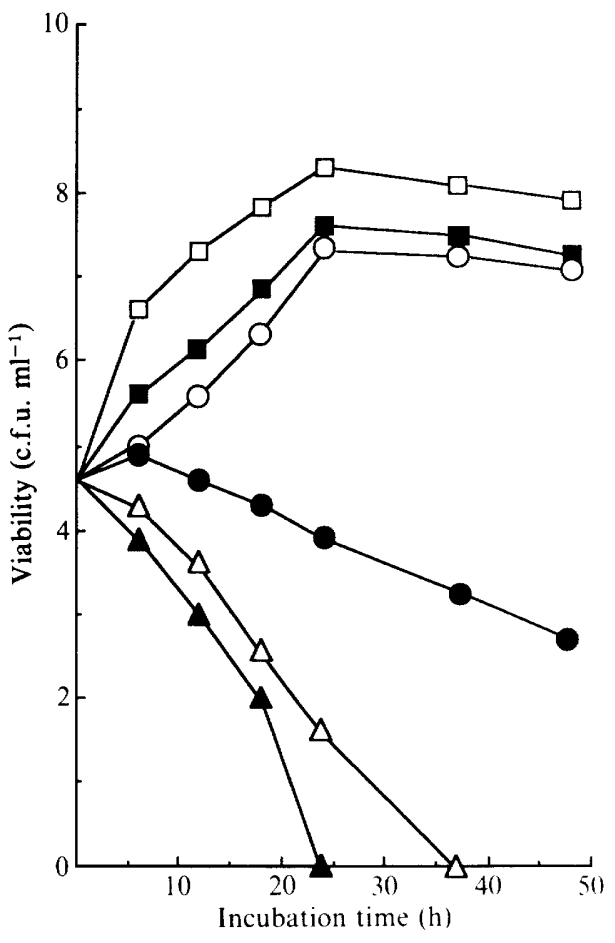

Fig. 2. Susceptibility of growing cells of $S$. mutans MT8148 to increasing concentrations of mutacin MT6223 (2.5-50 AU ml-1). $\square$, Control (no mutacin);, $2.5 ; \bigcirc, 5 ; \bullet, 10 ; \triangle, 25 ;$ and $\boldsymbol{\Delta}, 50 \mathrm{AU}$ mutacin $\mathrm{ml}^{-1}$.

Table 2. Inhibitory activity of mutacin MT6223 against strains of mutans streptococci

The bactericidal activity of mutacin was determined by measuring c.f.u. in BHI broth containing the mutacin. The inhibition of indicator strains in agar was determined by the stab culture technique and the results are expressed as the diameter $(\mathrm{mm})$ of the inhibition zone.

\begin{tabular}{|c|c|c|c|c|c|c|c|}
\hline \multirow[b]{3}{*}{ Species } & \multirow[b]{3}{*}{ Serotype } & \multirow[b]{3}{*}{ Strain } & \multicolumn{4}{|c|}{ Percentage inhibition in broth } & \multirow{3}{*}{$\begin{array}{l}\text { Inhibition } \\
\text { zone } \\
\text { diameter } \\
(\mathrm{mm})\end{array}$} \\
\hline & & & \multicolumn{4}{|c|}{ Mutacin concn $\left(\mathrm{AU} \mathrm{ml^{-1 }}\right)$} & \\
\hline & & & 10 & 25 & 50 & 100 & \\
\hline \multirow[t]{2}{*}{ S. cricetus } & \multirow[t]{2}{*}{$a$} & E49 & $19 \cdot 8$ & $58 \cdot 8$ & $86 \cdot 2$ & 100 & 18 \\
\hline & & HS6 & 0 & 0 & 0 & 0 & 0 \\
\hline \multirow[t]{2}{*}{ S. rattus } & \multirow[t]{2}{*}{$b$} & FAl & 0 & 0 & 0 & 0 & 12 \\
\hline & & BHT & $\mathbf{0}$ & 0 & 0 & 0 & 11 \\
\hline \multirow{11}{*}{ S. mutans } & \multirow[t]{5}{*}{$c$} & NG71 & 33.4 & $78 \cdot 1$ & 100 & 100 & 19 \\
\hline & & GS5 & $38 \cdot 2$ & $83 \cdot 2$ & 100 & 100 & 21 \\
\hline & & MT8148 & $35 \cdot 4$ & $82 \cdot 4$ & 100 & 100 & 20 \\
\hline & & Ingbritt & $36 \cdot 2$ & $78 \cdot 6$ & 100 & 100 & 20 \\
\hline & & MT4263 & $35 \cdot 4$ & $82 \cdot 2$ & 100 & 100 & 20 \\
\hline & \multirow[t]{3}{*}{$e$} & MT703R & $31 \cdot 0$ & $74 \cdot 0$ & 100 & 100 & 20 \\
\hline & & MT3567R & $35 \cdot 6$ & $79 \cdot 0$ & 100 & 100 & 20 \\
\hline & & LK3 & $34 \cdot 2$ & $81 \cdot 5$ & 100 & 100 & 20 \\
\hline & \multirow[t]{3}{*}{$f$} & MT6222 & $35 \cdot 2$ & $79 \cdot 0$ & 100 & 100 & 19 \\
\hline & & OMZ175 & $35 \cdot 4$ & $82 \cdot 6$ & 100 & 100 & 20 \\
\hline & & MT3940 & $35 \cdot 0$ & $82 \cdot 2$ & 100 & 100 & 20 \\
\hline \multirow[t]{6}{*}{ S. sobrinus } & \multirow[t]{3}{*}{$d$} & B13R & 0 & 0 & 0 & 0 & 11 \\
\hline & & OMZ176 & 0 & 0 & 0 & 0 & 16 \\
\hline & & MT4502 & 0 & 0 & 0 & 0 & 10 \\
\hline & \multirow[t]{3}{*}{$g$} & MT6223 & 0 & 0 & 0 & 0 & 0 \\
\hline & & 6715 & 0 & 0 & 0 & 0 & 10 \\
\hline & & MT4532 & 0 & 0 & 0 & 0 & 9 \\
\hline S. downei & $h$ & $\mathrm{MFe} 28$ & $15 \cdot 8$ & $41 \cdot 0$ & $74 \cdot 3$ & 100 & 17 \\
\hline
\end{tabular}




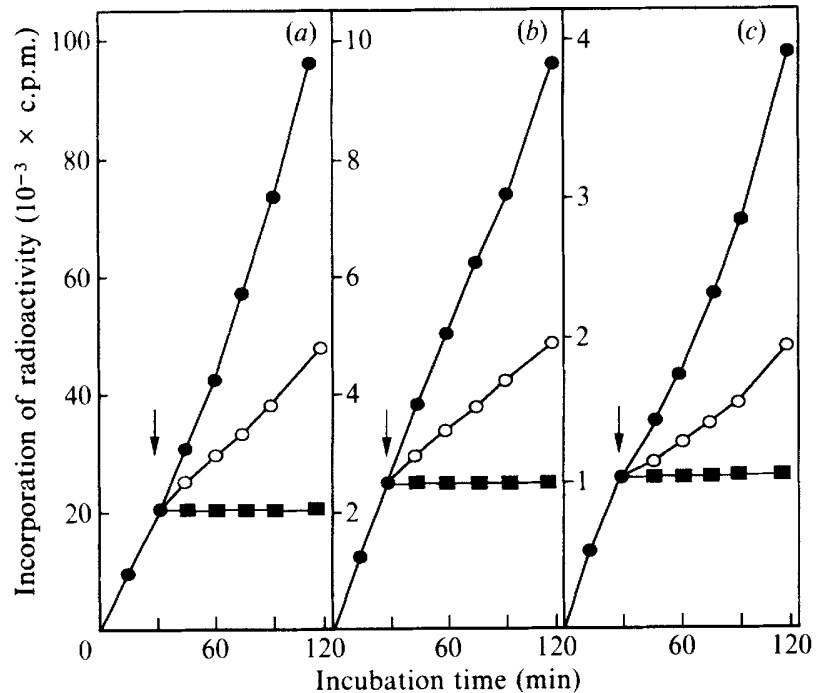

Fig. 3. Effect of the addition of mutacin MT6223 (indicated by arrow) on DNA, RNA and protein syntheses of $S$. mutans MT8148 grown in FMC broth containing $\left[{ }^{3} \mathrm{H}\right]$ thymidine $(a),\left[{ }^{3} \mathrm{H}\right]$ uracil $(b)$ or L$\left[{ }^{3} \mathrm{H}\right]$ glutamic acid $(c)$ as described in Methods. Samples $(1 \mathrm{ml})$ of the cultures were taken in triplicate over time to estimate the incorporation of radioactivity into cells. Control (no mutacin); $\bigcirc, 10$; and $\square$. 25 AU mutacin $\mathrm{ml}^{-1}$.

S. sanguis, but not against Staphylococcus sp., Actinomyces sp. and Lactobacillus sp. or Escherichia coli (data not shown). Addition of purified mutacin MT6223 to growing cells of $S$. mutans MT8148 resulted in a rapid inhibition of incorporation of the radioactive precursors of DNA, RNA and protein synthesis (Fig. 3).

\section{Inhibition of experimental caries development in rats}

Specific pathogen-free Fischer rats fed diet 2000 and infected with $S$. mutans MT8148R showed significantly fewer caries and lower plaque scores when mutacin ( 50 or $100 \mathrm{AU} \mathrm{ml}^{-1}$ ) was administered to these rats through drinking water (Table 3 ). These results indicated that administration of mutacin reduced the level of infecting $S$. mutans MT8148R in the oral cavity of rats, and that caries inhibition was dependent on the dose of mutacin.

\section{Discussion}

Mutacin MT6223 is the only bacteriocin isolated in a cell-free state from culture supernatant of $S$. sobrinus. Using chromatofocusing and cation exchange chromatography, we purified mutacin MT6223 to a single protein band in SDS-PAGE (Fig. 1). The purified mutacin was calculated to have a molecular mass of $6.5 \mathrm{kDa}$, and was stable chemically and physically. Treatment of the mutacin with papain or ficin resulted in a complete loss of activity. This indicates that mutacin MT6223 is protein/polypeptide in nature. However, the mutacin activity was not affected by the treatment of some proteases such as trypsin, pepsin, pronase $P$ and other enzymes, i.e. catalase, phospolipase $\mathrm{C}$, and lipase. We are currently investigating the detailed chemical structure of mutacin MT6223 in our laboratory.

In an earlier paper, we demonstrated that simultaneous inoculation of $10^{5}$ c.f.u. of $S$. sobrinus MT6223 inhibited colonization in rats by $S$. mutans MT6222, while a non-bacteriocinogenic mutant of MT6223 did not inhibit the colonization by $S$. mutans MT6222 (Kitamura et al., 1989). This result strongly suggested that in situ production of bacteriocin may modify microbial ecology in vivo, and that susceptible organisms of mutans streptococci and other related species can be suppressed by the mutacin locally produced in vivo. In the present study, cell-free mutacin MT6223 given to rats through drinking water did prevent the development of dental caries in rats that had been infected with $S$. mutans MT8148R, a serotype $c$ strain of mutans streptococci (Table 3). Similar findings were reported by others using bacteriocin from different origins. Fitzgerald et al. (1986) showed that daily application of

Table 3. Effects of mutacin MT6223 on caries development in the rat model

Specific pathogen-free Fischer rats fed diet 2000 and infected with $S$. mutans MT8148R were given drinking water with mutacin (50 or $100 \mathrm{AU} \mathrm{m}^{-1}$ ) or without mutacin. Dental plaque accumulation, caries scores and the $S$. mutans MT8148R attached on the mandible were evaluated as described in Methods.

\begin{tabular}{|c|c|c|c|c|c|}
\hline \multirow[b]{2}{*}{ Group } & \multicolumn{2}{|c|}{ Treatment } & \multirow[b]{2}{*}{$\begin{array}{c}\text { Recovery of } \\
\text { MT8148R (c.f.u.) }\end{array}$} & \multirow[b]{2}{*}{ Plaque score } & \multirow[b]{2}{*}{ Caries score } \\
\hline & Infection & $\begin{array}{c}\text { Mutacin } \\
\left(\mathrm{AU} \mathrm{ml} \mathrm{ml}^{-1}\right)\end{array}$ & & & \\
\hline A & No & 0 & 0 & $0.73 \pm 0.16$ & $6 \cdot 8 \pm 3 \cdot 1$ \\
\hline $\mathrm{B}$ & Yes & 0 & $2 \times 10^{6}$ & $1.69+0.14$ & $49.7 \pm 9.5$ \\
\hline $\mathrm{C}$ & Yes & 50 & $6 \times 10^{4}$ & $0.99 \pm 0.12^{*}$ & $26 \cdot 6 \pm 11 \cdot 4^{*}$ \\
\hline D & Yes & 100 & $2 \times 10^{4}$ & $0.92 \pm 0.15^{*}$ & $13.4 \pm 3.7^{*}$ \\
\hline
\end{tabular}

${ }^{*} P<0.0001$ by Student's $t$ test against group B. 
staphylococcin 1580 in the cheek pouches of Syrian hamsters inhibited caries development by approximately $50 \%$. This bacteriocin was obtained from a clarified culture supernatant of Staphylococcus epidermidis 1580 (Jetten et al., 1972) and was found to be effective in vitro against various strains of $S$. mutans and other Grampositive bacterial species (Fitzgerald et al., 1986). Mutacin C3603 derived from $S$. mutans C3603, a serotype $c$ strain of mutans streptococci, was examined for in vivo caries inhibition abilities (Ikeda et al., 1982; Ooshima et al., 1985). In these experiments rats infected with an S. mutans strain and given mutacin C3603 developed less caries than the controls. When compared with these findings, mutacin MT6223 was shown to be an effective agent, in terms of in vivo activities, to inhibit dental caries in animal experiments.

Earlier studies indicated that few strains among many clinical isolates of $S$. mutans produced a cell-free mutacin, although $80 \%$ of the strains tested were demonstrated to produce some bacteriocin-like substance when grown in agar medium (Hamada \& Ooshima, 1975a; Rogers, 1976). S. mutans GS5 (Paul \& Slade, 1975), C3603 (Ikeda et al., 1982) and JH1000 (Hillman et al., 1984), which are all serotype $c$ strains of mutans streptococci, were reported to synthesize a cellfree mutacin. However, the properties of mutacin MT6223 were clearly different from these preparations. The molecular mass $(6.5 \mathrm{kDa})$ of mutacin MT6223 was higher than that of mutacin C3603 $(4 \cdot 8 \mathrm{kDa})$ and JH1000 (under $1 \mathrm{kDa}$ ), and lower than that of mutacin GS5 $(20 \mathrm{kDa})$, although the estimation method of molecular mass was different in each case. Further, papain treatment of mutacin C3603 did not inactivate its activity (Ikeda et al., 1982), but did inactivate mutacin MT6223 completely as shown in this study. Differences in the sensitivity spectrum of the indicator strains were also noted among these three mutacins. Notwithstanding the differences in various properties, we now have strong evidence to indicate that bacteriocins, including mutacins, can affect microbial ecology in the oral flora and some bacteriocins may function to suppress caries development if they have the ability to inhibit the growth of mutans streptococci in vitro (Fitzgerald et al., 1986; Ikeda et al., 1982; Ooshima et al., 1985; Weerkamp et al., 1977).

In conclusion, the present study demonstrates that mutacin MT6223 selectively inhibits the growth of mutans streptococcal strains, especially in strains belonging to serotypes $c, e$ and $f$ in vitro and in vivo. This bacteriocin may be a good candidate for use as an anticaries agent.

We thank Professor Bernard Russell, University of Florida, Gainesville, Florida, USA, for correcting the English version of this manuscript. The funds to support J.P.L.-R. during his stay in Osaka were kindly provided by the Japanese Government Scholarship for Research Students.

\section{References}

DAJANI, A. S., ToM, M. C. \& LAW, D. J. (1976). Viridins, bacteriocins of alpha-hemolytic streptococci: isolation, characterization, and partial purification. Antimicrobial Agents and Chemotherapy 9, 81-88.

Delisle, A. L. (1986). Properties of mutacin b, an antibacterial substance produced by Streptococcus mutans strain BHT. Microbios 46, 21-28.

Fitzgerald, R. J., Mohart, R. E., Marquez, C. \& Adams, B. O. (1986). Inhibition of caries in hamsters treated with staphylococcin 1580. Infection and Immunity 54, 288-290.

Hamada, S. \& Ooshima, T. (1975a). Production and properties of bacteriocins (mutacins) from Streptococcus mutans. Archives of Oral Biology 20, 641-648.

Hamada, S. \& OOSHIMA, T. (1975b). Inhibitory spectrum of bacteriocin-like substance (mutacin) produced by some strains of Streptococcus mutans. Journal of Dental Research 54, 140-145.

HAMADA, S. \& TORII, M. (1978). Effect of sucrose in culture media on the location of glucosyltransferase of Streptococcus mutans and cell adherence to glass surfaces. Infection and Immunity 20, 592-599.

Hillman, J. D., Johnson, K. P. \& YAPHe, B. I. (1984). Isolation of a Streptococcus mutans strain producing a novel bacteriocin. Infection and Immunity 44, 141-144.

Ikeda, T., Iwanami, T., Hirasawa, M., Watanabe, C., McGhee, J. R. \& Shiota, T. (1982). Purification and certain properties of a bacteriocin from Streptococcus mutans. Infection and Immunity 35, 861-868.

JetTen, A. M., Vogels, G. D. \& DE Windt, F. (1972). Production and purification of Staphylococcus epidermidis bacteriocin. Journal of Bacteriology 112, 235-242.

KeYES, P. H. (1944). A method of recording and scoring gross carious lesions in the molar teeth of Syrian hamsters. Journal of Dental Research 23, 439-444.

Kitamura, K., Masuda, N., Kato, K., Sobue, S. \& Hamada, S. (1989). Effect of a bacteriocin-producing strain of Streptococcus sobrinus on infection and establishment of Streptococcus mutans on tooth surfaces in rats. Oral Microbiology and Immunology 4, 65-70.

LaEMmLI, U. K. \& FaVre, M. (1973). Maturation of the head of bacteriophage T4. I. DNA packing events. Journal of Molecular Biology 80, 575-599.

Ooshima, T., Sobue, S., Hamada, S. \& Kotani, S. (1981). Susceptibility of rats, hamsters and mice to carious infection by Streptococcus mutans serotype $c$ and $d$ organisms. Journal of Dental Research 60, 855-859.

Ooshima, T., Yasufuku, Y., Izumitani, A., Sumi, N. \& Iwanami, T. (1985). Effect of mutacin administration on Streptococcus mutansinduced dental caries in rats. Microbiology and Immunology 29, 11631173.

Ooshima, T., Hashida, T., Fuchihata, H., Fujiwara, T., Yoshida, T., Izumitani, A., Sobue, S. \& Hamada, S. (1991). Dental caries induction in hyposalivated rats. Caries Research 25, 138-142.

Paul, D. \& Slade, H. D. (1975). Production and properties of an extracellular bacteriocin from Streptococcus mutans bactericidal for group A and other streptococci. Infection and Immunity 12, 13751385.

Regolati, B. \& Hotz, P. (1972). Cariostatic effect of glycerophosphate. Helvetica Odontologica Acta 16, 13-18.

RoGERS, A. H. (1976). Bacteriocinogeny and the properties of some bacteriocins of Streptococcus mutans. Archives of Oral Biology 21, 99104.

Terleckyj, B., Willet, N. P. \& Shockman, G. D. (1975). Growth of several cariogenic strains of oral streptococci in a chemically defined medium. Infection and Immunity 11, 649-655.

Weerkamp, A., Vogels, G. D. \& Skotnicki, M. (1977). Antagonistic substances produced by streptococci from human dental plaque and their significance in plaque ecology. Caries Research 11, 245-256 